\title{
Good Governance vs Sound Governance: A Comparative Theoretical Analysis
}

\author{
Rendra Setyadiharja \\ Lecturer of Government Science Department \\ STISIPOL Raja Haji \\ Tanjungpinang, Indonesia \\ rendra tanjungpinang@yahoo.co.id \\ Dewi Kurniasih \\ Lecturer of Government Science University Komputer \\ Indonesia Computer University \\ Bandung, Indonesia \\ Email: dekur0105750@yahoo.com
}

\author{
Poppy Setiawati Nursnaeny \\ Lecturer of Government Science Universitas Jayabaya \\ Jayabaya university \\ Jakarta, Indonesia \\ poppysetiawati@gmail.com \\ Neng Suryanti Nengsih \\ Lecturer of Government Science Department \\ STISIPOL Raja Haji \\ Tanjungpinang, Indonesia \\ suryatra@yahoo.com
}

\begin{abstract}
Good governance is a fresh air, especially for Indonesia governance today. This theory was created in order to improve governance in various countries including Indonesia. With the concept, the governance is expected to be able to reach the high level of transparency, accountability, rule of law, equality, effective and efficiency in government and certainly free of corruption. However unwittingly behind this concept actually weaken the position of the government as an entity of power in a state, so easily influenced by foreign policy. As the antithesis, it appears a new concept called the sound governance. However, the sustainability of this new concept is certainly invites a question mark, whether the concept is able to counter and opposed to the concept of good governance or will only promise a concept in the false hope for developing countries, including Indonesia. The purpose of this reseacrh is to describe a theoretical comparison between good governance and sound governance and how the actualization of the concept in Indonesia. So by comparison, it is known, which concept would be more relevant to the development of the theory of government and governance conditions in Indonesia today. This reseacrh is a qualitative comparative research, using the technique library reseacrh with content analysis approach, this research will produce the critical concept of both theories that would produce a conclusion which theory is more relevant as a theory that really constructive to current governance and public administration, especially in Indonesia.
\end{abstract}

Keywords- Good Governance; Sound Governance; Public Administration; Government; Governance

\section{INTRODUCTION}

Toward the onset of political reform in Indonesia or around 1996, several international institutions such as the United Nations Development Program and the World Bank introduced a term called good public governance or good governance, hereinafter abbreviated as GG. The popularity of this terminilogy is prevalent among governments, academics and non-governmental organizations in line with the provision of assistance directed at developing GG. Because it is being promoted so nowadays the term GG becomes a very often spoken word in various discussion spaces such as discussion of democracy and autonomy. The term governance is left in its original form because it is difficult to find the right match. Many also translate into governance. Whatever the translation of governance refers to the notion that power is no longer solely owned or a government affair. Governance emphasizes the implementation of governing functions jointly by governments and other institutions. Even non-governmental institutions [1].

GG in question is the process of organizing state power in implementing the provision of public goods and services called governance or good governance. The best practice is called GG. In order for GG to become a reality and work well, it requires commitment and involvement of all parties, namely government and society. An effective GG demands good coordination and integrity, professional and work ethic and high morale. Thus the application of the concept of GG in the implementation of state government power is a challenge in itself [2].

GG itself in its emergence was captured by the international community as an elixir of international development and has been trusted by donor agencies for more than the last ten years. This concept has become a magical word that can cross the boundaries of dimensional and sectoral conversations. The dimensional limit is when we are faced with economic, political, social and even environmental conversations. Sectoral boundaries include a range of sectors such as agriculture, poverty, transport, corporate business, sanitation, and pollution control. GG became phenomenal when it found the missing link between the work of government reform and poverty alleviation [3].

Along with the spirit of reform that has colored the utilization of state apparatus with the demand to realize the state administration that is able to support the smoothness and 
integrity of the execution of duties and functions of state administration and development, by practicing GG principles. GG has also become a concept that is able to cultivate people's desire in tackling corruption, collusion and nepotism, so as to create a clean government and able to provide public goods and services as expected by the community [2], [4].

GG success story has also been told by Tendler in his book Good Government in The Tropic [5] which explains that GG is then emphasized on the aspect of dedication as a factor affecting good performance and best practices. Tendler [5] also explains that government officials in successful programs demonstrate high dedication to their work. So with the spirit of GG which is then interpreted in dedication is to support the performance of the employees. GG has also colored the practice of regional autonomy in various countries. In the relatively established countries of democratic life there is wide autonomization for local governments to manage their own needs and interests, while the central government deals only with strategic and vital matters in order to preserve the integrity of the state. From this it is no exaggeration to say that democratization and autonomization are influential and linearly influenced by GG officials in local government [1].

But behind all the merits of the GG concept, it was born and colored governance practices almost all over the world, but this concept is regarded as a concept that is nothing more than an imperialist and colonialist concept. In a revelation made by Tanzanian President Julius K. Nyerere before the UN Conference in Africa in 1998, saying that GG is no more than imperialist and colonialist, GG will only degrade the structure of developing countries, while the world's law enforcement business is getting bigger [3]

GG is an issue, concept and assessment born in the globalization stream to reduce corruption, economic crisis and financial crisis. But $\mathrm{GG}$ is a product that is a wave of injections in the effort to eradicate the disease in the third world by obliging from the requirements of the World Bank. One example, the crisis in Africa has brought a clear message in introducing a new concept to counter what the World Bank identified as a crisis of government or bad governance. Of course in terms of injecting such governance ideas, has also carried the discourse as a sweetener to be accepted and legitimated by the dictaktorial power that was a lot of power at the time [6]

GG here is more defined as a matter of power aimed at the management of social and economic resources of the country for development [6]. Experience in post-crisis Africa and postcold war has become a background and climate that illustrates the pressures of free market forces and liberal democracy. GG in that context is the legal political imposition controlled by industrial countries and international agencies including the world's donor agencies in shaping the tightly governed government of the market [6].

This is the birth and womb of the great agenda of globalization constructed by neo-liberal ideology. Neo-liberal is one part of a hegemon project that concentrates power and prosperity on a group of elites in the world, especially those who take advantage and interest financially within each country. Neoliberalism is therefore inseparable from globalization and imperialism. The most fundamental character in neoliberalism is the system of using state power to require financial market policies in the domestic process [6]. Later in the context of globalization, neoliberalism became the mainstream of political and economic policy, revealing the face of capitalistic organizations that clearly undermined the power of civil society through the strategy and technology of power, including the use of law as a control medium. This means that neoliberalism becomes a destructive hegemonic system and exploits the majority. The World Bank, the International Monetary Fund (IMF) and the World Trade Organization (WTO) are the vehicles of their economic politics and joined a group in the United States since 1944 called "Breetonwoods". The group seeks to encourage more market-driven economic growth due to the "Washington Consensus" by promoting privatization, free trade, exportoriented growth, financial capital mobility, deregulated labor markets and macroeconomic savings policies [6].

Born of criticism against GG then gave rise to the birth of a new concept which was later sparked by Ali Farazman in 2004 which he wrote in a book entitled "Sound Governance-Policy and Administration Innovation" [7]. According to Farazmand [7] in the book, explains that Sound Governance hereinafter abbreviated as SG is a concept to increase global complexity, challenges, threats and opportunities that will affect a nation state, local government, citizens, organizations and systems administration. The key to all these elements is administrative policy and innovation.

For all the criticisms of the GG and the birth of SG that will color the governance around the world will certainly lead to a conceptual discourse on governance. Therefore, this study is intended to perform conceptual theoretical comparisons. Whether criticism of GG is a reality that will harm a state institution or the emergence of $\mathrm{SG}$ as a concept that is considered a renewal and a fresh breeze in governance, or even a utopian concept that is not easy to implement. However GG with all its weaknesses, has been implemented for a long time, while SG will only be born and coloring the governance in this era of globalization. Will the GG and SG be the concepts and theories that complement each other as a concept in governance.

\section{THEORETICAL FRAMEWORK}

\section{A. Concept of Good Governance}

In the context of GG, then the first definition needs to be elaborated is the sense of governance. The World Bank [4] defines the way state power is used as managing economic and social resources for development and society. While UNDP [4] defines the exercise of political, economic, and administrative authority to manage a nation's affairs at all levels. So [4] itself translates that based on the definition of the governance has three elements, namely: 
1. economic governance includes a decision-making process that facilitates equity, poverty, and quality of live,

2. political governance is the decision process for policy formulation,

3. administrative governance is the system implementation process of policy.

While [5] explains that governance is defined as mechanisms, practices, and procedures of government and citizens manage resources and solve public problems. In the concept of governance the government only becomes one of the actors and is not always the most decisive actor. In terminology governance is defined as governance, so there are still many who think that governance is a synonym of government. Then [5] continues the explanation that the true concept of governance must be understood a process, not a structure or institution. Another notion as stated by Leach and Percy-Smith [5] explains that government has a political and government understanding that governs, does something, provides service, while the rest of "us" is a passive recipient. Syakrani and Syahriani [8] describe a notion cited from Cagin which suggests the concept of governance refers to the institutions, processes and traditions that determine how power is held, decisions are made, and the voices of citizens.

While good in good governance contains two meanings as follows, firstly, values that uphold the wishes or desires of the people, and values that can improve the ability of the people in achieving national goals, independence, sustainable development and social justice. Secondly, the functional aspect of effective and efficient governance in the performance of its duty to achieve that goal [2], [4]. Next Sedarmayanti [2], [4] explains based on this understanding, then good governance oriented on:

1. ideal orientation, a country directed at achieving national goals. The orientation is based on democratization in the life of the state with its constituent elements such as legitimacy, accountability, human rights guarantees, autonomy and power sharing, and guarantees of civil society oversight,

2. governance that functions ideally, that is effectively and efficiently in the effort to achieve national goals. This second orientation depends on the extent to which governments have the competence and extent of effective and efficient political and administrative structures and mechanisms.

The World Bank [3] places restrictions on GG as an efficient public service, a reliable judicial system, and a government that is accountable to the public. The European Community [3] defines GG as the management of sound socioeconomic policies, democratic decision-making, government transparency and adequate financial accountability, the creation of a friendly environment for markets for development, measures to combat corruption, rule of law, respect for human rights, freedom of press and expression. While UNDP [3] gives GG an understanding as a consensus reached by governments, citizens and the private sector for governance in a country. Another explanation of GG constraints is as explained by the OECD and the World Bank [2] synthesizing GG's with the implementation of solid and responsible development management, in line with democracy and efficient markets, avoidance of misallocation of scarce investment funds, and the prevention of corruption, both politically and administratively, running the budget discipline, and the creation of legal and political framework for the growth of entrepreneurial activity.

Based on all the definitions and limitations of GG, the characteristics proposed by UNDP [2] which will strengthen each other and can not stand alone are as follows.

1. Participation. every citizen has a voice in decisionmaking, either directly or intermediation of the legitimate institution representing his or her interests. Participation like this is built on the basis of freedom of association and talk and participate in a constructive manner.

2. Rule of Law. The legal framework should be fair and implemented without distinction, especially human rights law,

3. Transparency. Transparency is built on the freedom of information flow. Institutional processes and information are directly accepted by those who need them. Information should be understandable and monitorable.

4. Responsiveness. Institutions and processes should try to serve every stakeholder.

5. Consensus orientation. GG mediates different interests to get the best option for wider interests in terms of policies and procedures.

6. Effectiveness and efficiency. Processes and institutions produce according to what has been outlined by using the best available resources.

7. Accountability. Decision makers in government, the private sector and communities are accountable to the public and stakeholder institutions. This accountability depends on the organization and nature of the decision made, whether the decision is for the internal or external interests of the organization.

8. Strategic vision. Leaders and the public should have GG perspectives and broad and far-reaching human development in line with what is required for such development.

The actor in GG as explained by Sedarmayanti [2] consists of three namely, State, Society and Private Sector. So Sedarmayanti [2] also explains that in GG, the State becomes the most important domain in realizing $\mathrm{GG}$, since the regulatory functions that facilitate the domain of private business sector and society, as well as the administrative 
functions of government administration are attached to this domain. Sedarmayanti [2] then continue his explanation that from the aspect of government, GG can be seen through aspects:

1. Laws / policies aimed at the protection of social, political and economic freedom,

2. Administrative competence and transparency. Ability to plan and implement efficiently, ability to simplify organization and administrative model and information disclosure,

3. Decentralization. Regional decentralization and deconcentration within departments,

4. Creation of a competitive market. Improved market mechanisms, enhancing the role of small entrepreneurs and other segments in the private sector, deregulation and the ability of governments to manage macroeconomic policies.

\section{B. The Concept of Sound Governance}

By definition the SG can not be separated from the sense of governance that is part of this concept, but SG is considered as an alternative to GG has several reasons as described by Farazmand [7] first more comprehensive than any other concept reviewed earlier and contains elements of global or international governance the important one. Second, it also contains the normative or technical and rational features of GG. Yet this results in a balanced view of less skewed governance, and considers the pure features of an indigenous governance system that may conflict with the dominant neocolonialist forces structure. In other words, a government is said to be sound or clear. Although the system is in conflict with imperialist interests and its interventionist policies. Third, the concept of SG has the characteristics of governance quality that is superior to GG, and superior to GG, and is considered more clearly technically, professional, organizational, managerial, political, democratic and economic. Fourthly, SG fits the constitutional value and is responsive to international norms, rules and regimes.

In $\mathrm{SG}$ the term governance shows a more comprehensive understanding. Governance by Farazmand [7] Governance means the process of participation in the handling of social, economic, and political affairs of a state or local community through structures and values that reflect society. In this case governance is used as a broader concept than a traditional, unilateral and authoritarian form of government in which the governing elite is only sitting in unilateral command positions.

In SG, Putra [9] explains that the interaction of various elements is a reality that can not be denied. The first thing to do by bureaucrats is to understand the reality of the social environment situation. An impossible situation can only be answered in a very simple way that is a procedural routine. [9] Farazmand [7] then explains that the social reality is full of dynamic interaction, it must emerge three main things, namely diversity, complexity, and tension, these three embodiments will be the basis for the conceptual construction of SG itself. Then Farazmand [7] and Putra [9] explain that the three basic realities as SG awareness in handling social reality are described as follows.

1. Diversity. In the reality of government, the government is faced with a reality of diversity of thoughts, opinions and demands and demands from the community which then becomes a process in the government system that becomes input, process, output and feedback. This will result in a process of checks and balances, between the public and the government. This should be addressed by making it values and energy to encourage the growth of innovation and creativity within the body of government organizations.

2. Complexity. This is as a result of the first reality of diversity. This reality is demonstrated by the complexity of the social environment, so it is not uncommon to find groups of positions and opposition. Moreover, in a democratic country, the complexity of its diversity is more visible and SG wants to invite us to look at something complex and must be addressed with optimism. This will lead the government to be responsive in responding to all the complex issues of society and to think of solutions.

3. Tension (intensity). The complexity that occurs within a diverse society will result in tension or intensity in the process of governance domestically and internationally. The tension is not the connotation of destructive conflict, but the intensity of communication among the elements.

Furthermore, the actors in the SG as described by Putra [9] are State, Civil Society, Private and International Actors, three of the four actors are actors on GG. So, SG did not simply move the three actors in the GG into SG, but also changed the way GG's current view of the role and position of the state, civil society and the private sector in governance.

Like GG, SG also has indicators, Farazmand [7] and Putra [9] describes the SG indicators are as follows.

1. Process. SG contains a process that governs all interactions of all elements or stakeholders involved, this is the meaning that GG wants to generate. But $\mathrm{SG}$ is not about internal and external processes, it also has structure.

2. Structure. A structure is a constitutive element of elements, actors, regulatory rules, procedures, decision-making frameworks, and authoritative sources that can sanction or legitimize government processes. Its structural form is formed and runs vertically and horizontally and is influenced by various international and external factors, focus and international. This process explains how governance is run, where it defines and provides direction for the process.

3. Cognition and value. The cognitive dimension or value represents a unit value system or deviant in a governmental structure or process. Inside $\mathrm{SG}$ it 
generates healthy and dynamic values that underlie the dimensions of structure and process. So that in SG must minimize for the occurrence of a deviation.

4. Constitution. Furthermore, the most important dimensions of governance and SG are the constitution of governance and governance system. The Constitution is the basic document that becomes the blueprint of governance.

5. Organizations and institutions. Another dimension of governance within $\mathrm{SG}$ is the organizational and institutional component. In this context what is meant by governance institutions, how well these institutions are run in coordination with other government institutions. The structure and process of governance or policy is determined by governance institutions and without institutions there will be no SG.

6. Management and performance. The managerial and performance dimensions of $\mathrm{SG}$ have a close relationship. This is an integral part of the whole system. But just performance is not enough, this should produce the desired result, exactly that can be translated into institutional and system legitimacy. The dimension of management is like a glue, exactly the transmission of a system that produces the desired results. Management should be given around the latest knowledge, technology, capabilities, resources and expertise, essentially constant updating through research and development, training and capacity building.

7. The next policy is the policy dimension of SG that provides clear guidance, direction and control for the elements or dimensions of process, structure and management.

8. Sector. Another dimension of $\mathrm{SG}$ is the sectoral features that make up all other dimensions. The sectoral dimensions of governance are important because they are focused on specific sectors such as industry, agriculture, rural, municipal, scientific, research and development, education, health, transportation and other areas. Sectoral SG requires direct participation of the people, capable management and knowledge and expertise in the performance of public organizations.

9. International Strength or Globalization. The dimensions of $\mathrm{SG}$ and of crucial importance are global or international dimensions.

\section{RESEARCH METHODOLOGY}

This research is done by research of reseacrh library method. Where do literature review related to research object. The literature analyzed is related to the two concepts that become the variables in the study. The research approach used is qualitative approach. Data analysis techniques are also using qualitative data analysis techniques. Where the data have been obtained and then grouped in accordance with the purpose of this study, then the data in the form of grouped text and do the conclusion to be analyzed.

\section{RESULTS AND DISCUSSION}

\section{A. Comparison of Good Governance and Sound Governance Indicators}

GG is implemented with nine indicators of participation, rule of law, transparency, responsiveness, concensus orientation, effectiveness and efficiency, accountability, and strategic vision. In the GG concept it is stated that these indicators are the embodiment of a solid and responsible, efficient and effective governance by maintaining a constructive interaction between constructive domains between the three domains of the country, the private sector and society. So the effort to realize the GG is also an attempt to make improvements to the state administration system applicable to a country as a whole [2]. The GG indicator is considered to be a process interpretation. Where according to Farazmand [7], the government with the GG concept is required to run the government process with predetermined indicators and without thinking where the purpose. With that indicator Putra [9] explains that GG has been wrong in implementing the concept. With emphasis on the process of a country impressed imposed, moreover the estuary of an indicator must be on the same term that is "Good". But the translation of the word "Good" is still very absurd addressed to whom. With the above indicator, a country is forced to do the same things without prioritizing local values and innovation. Because if all countries out of the corridor set by GG, and in case of failure GG unable to cope. A further problem with the indicator is as explained by Putra [9] that problems arise when the organization of these indicators is carried out simultaneously with the process of uniformity. This is then able to eliminate local values that could actually be a factor supporting the success of government.

While in the SG, do not use indicators but the dimensions are, processes, structures, cognitions and values, constitutions, organizations and institutions, management and performance, policy, sector, international forces or globalization [7]. The word dimension here is important to say the term indicator. For as in GG and other hegemonic concepts. The success indicator is an absolute prerequisite for an idea to be said to be implementive. Because an implementive idea is an idea that can be implemented and can be measured to the extent that its performance can be achieved in the field. Therefore, SG does not want to repeat the same conceptual mistake, then SG put forward dimension rather than indicator. With the concept of the dimension of flexibility in the area of implementation, the diversity and creativity of actors in the field become widely expressed without having to be chaos [9]. As Farazmand [7] points out, the dimension of SG is more concerned with the 
process of achieving objectives than discussing the problem of how principles are carried out to achieve goals. So the spirit of this $\mathrm{SG}$ dimension is innovation. Innovation is key in $\mathrm{SG}$, innovation in policy and administration is central to SG. Without innovation in government policies and administration will fail and will not be efficien, lose the capacity to govern and become a target of criticism and fail.

\section{B. Comparison of the Role of Good Governance and Sound Governance Actors}

Furthermore, the governance perspective has a number of new orthodoxies in managing a country that relies on six main principles [10]:

1. The state remains a key player in terms of dominance and hegemony, but the state is an equal actor who has sufficient capacity to mobilize community and market actors to achieve common goals,

2. The state is no longer a "formal power" center but as a centrum of "political capacity"

3. States should share power and influence to transnational organizations aside, such as the NonGovernment Organization and the private sector, and to the downward transnational organizations of society,

4. States should relax political control and organizational unity in order to encourage segments outside the country to develop a solid, autonomous and dynamic exchange and partnership

5. The state must involve elements of the private sector on the agenda of decision-making and the delivery of public services

6. State organizers must have responsive, adaptation, and public accountability.

If we look at the explanation above, then the emergence of governance resulted in decreasing role of state. This is also due to the emergence of the economic crisis in the 1980s, where the concept of governance began to develop. The role of government at that time weakened because it is considered as the root of economic problems that hit, so that emerged a way for the economy to be controlled by the private sector. As a result the role of the state is limited, because the role of the state is limited by the involvement of the private sector and the public. Under such conditions, governance is considered a savior for a newly democratized country. Wiratraman [6] explains that GG has been systematically designed to respond to the problems of corruption, economic and financial crisis that are considered "diseases" in poor and developing countries. The World Bank as an incarnation institution of this concept introduced the concept of public sector management program in order to treat better governance especially in the framework of development assistance requirements.
The Organization for Economic Cooperation and Development in 1992, has used the collapse of the Soviet Union, as a momentum to justify a liberal ideological system that essentially is: (1) upholding human rights values in particular the rights and freedoms of individuals, (2) democracy, (3) Rule of Law, (4) free market and (5) environmental concern [11]. Since then GG in the recipient country has been one of the requirements by international financial institutions, and since then the beginning of the wave of injections in the effort to eradicate the disease in the third world is done, by requiring some requirements from the World Bank. Certainly wrapped up with the lure of democratization that will strengthen development for a third world country that has just escaped the authoritarian regime.

According to Stoke and Gathi in Wiratraman [6] that GG in that context is the legal political imposition controlled by industrialized countries and international agencies in shaping market-wide government.

Then as Putra [9] explains basically two great ideas about the position and role of the state or government in GG are as follows.

1. Minimal intervention from state or government over many aspects of nation-state life and more take a "let the working market" attitude,

2. The state or government must be controlled by the check and balances mechanism whereby the mechanism is ultimately subject to the willingness of international and domestic markets.

Putera [9] suggests that countries in GG concept should be market-friendly. In order for the government to be marketfriendly, the government must rely on foreign debt, and that is what is regarded as a good government. Government-friendly markets are governments that make regulations and institutions aligned with the interests of foreign investment and safeguard people's purchasing power by providing public services to the people. But to finance it all governments have to rely on foreign debt, which then generates first, the people and the government bear the burden of foreign debt to succeed the creation of a market-friendly government, second, foreign investors have a favorable and cheaper investment climate because they are just waiting for the government's work and do not have to finance themselves; third, the World Bank and other international donors and creditors are getting profit from credit installments plus interest earned by selling GG concept.

Thus, Putra [9] again explains that there will arise an element of control over a state that is the institutions outside the country that ultimately control is largely determined by the willingness of the market or the strength of the multi-national financiers. The control institutions are International Financial Institutions such as the World Bank, IMF and ADB, Private Sector covering investors and private companies and Civil Society covers a diverse group of people but mainly touted as academics, NGOs, CSOs and mass media. 
However, with the relationship between the actors involved, GG never pay attention and take into account international actors in the implementation of the concept. As if allowing international actors to intervene in a country with a concept but does not take into account the influence of international actors. GG focus is just how local governments do development but without seeing how much the power of a region that has been controlled by foreigners.

This is what causes in SG to see the wider actor. SG actually just wants to answer and save the local interest so as not exploited by international actors by selling a product called GG. Farazmand [7] explains that SG has a much more comprehensive view with four actors - the state, civil society, the private sector and the international community. These international powers include global corporations, international organizations and agreements. In SG's view, the GG implementation of his life is only concerned with the interaction between government in certain countries, certain business people and people in certain countries. Surely this is very naive, because the fact that a very large and powerful actor on top of the elements is not included in the count, the actor is the international world.

In $\mathrm{SG}$ one of the novelty is the existence of four actors in its implementation, namely local, national, regional and international. The four are not only approached in depth one by one, but also viewed the interrelationship of each other. This is what distinguishes very striking SG and GG. Because the ideas and concepts that exist in the GG only dwell on two levels only, namely governance reform at the local and national levels. Even GG often focuses attention only on the local level only. Greater attention from SG to the four levels of governance departs from the realization that the existence of these four levels is real [9].

\section{Good Governance Criticism and Expectation of Sound Governance}

In the analysis of this context, we will explain criticisms of GG and how expectations are developed by SG. It does not mean to want to side with GG, but in this case will explain how the conceptual outlook and theory of things about GG, then with the emergence of SG, will see how the expectations of this concept in governance. Criticism of GG has grown and become one of the things that matters for GG survival. Both criticism of the actors, of the indicators and of the concept as a whole. The first criticism, based on the analysis of Syakrani and Syariani [8] explains that GG concept itself is still problematic, good according to whom and in the dominant political order. This question arises because of the argument that the mainstreeming of this concept to the developed countries carries the hidden agenda of capitalism, especially those sponsored by the IMF, World Bank and WTO. Voice of militant activity quoted from Dwipayana and Eko [8] raised critical questions such as "Who is GG? It's the neoliberal thinking of the IMF and World Bank versions that do not take sides with the people, but on the market ". Then Syakrani and Syahriani [8] also explained that there is another analysis which also suggests that alignment of entities (private sector) with government or state entities in GG's theoretical frameworks could have significant negative implications for state authorities to regulate private action, especially corporations global in developing countries. This tendency or likelihood needs to be cautioned that mainstreeming and institutionalization of GG principles is not used as another cunning strategy of foreign countries colonizing other countries. Criticism is also explained by Syakrani and Syahriani [8] the mainstreeming allocation of the GG concept with the deepening of the vision of the IMF, World Bank, WTO or global capitalism to developing countries related to the efforts of institutionalization of Good Economic Governance which allegedly not pro poor, The GG that is rife in recent years here is attributed to the Libertarian Governance model context.

Another criticism that emerged against GG was also explained by Putra [9] which explains GG as an ideology that will pave the way for a wider path for the entry of neoliberalism into the awareness space of nation-states around the world. Like command troops serving as pioneer troops to pave the way for regular forces, the GG concept is a unit that will undermine the most core base of the anti-liberalism and anti-neoliberalism awareness of the concept of what is good in the management of a nation state. In this case the GG concept really implements the hidden power of the language. Then more clearly Putra [9] explains as the conclusion of the criticism of GG that in its function as an ideology of GG concept in a systematic and intensive move with the methodology of the steps as follows.

1. The concept teaches that there are factors leading to the failure of economic development of developing countries so that these factors must be eliminated,

2. The concept teaches that the World Bank and IFIs have managed to find a panacea recipe for eliminating factors that are nothing but the GG concept itself,

3. The concept teaches that the concept is the only good recipe for solving the problem of failure of developing country economic development,

4. The concept teaches that the causes of failure cause economic development to fail because it implies the perfect functioning of the market mechanism, and therefore the core strategic of the prescription is to encourage developing country governments to harmonize government processes and policies in such a way as to be conducive to the ongoing mechanism the perfect free market and without a hitch,

5. The concept teaches that the governments of developing countries will be deemed not to apply the concept GG will be considered bad governance, so because it is not a good government.

Based on it all, the GG is considered a compelling concept, especially for developing countries to follow the concept, and if not then it would be considered an impartial 
state. It is clear that GG is a supposedly grasping concept that positions itself as an ideological value for all countries.

Further analysis is as explained by Wiratraman [6] explaining in his writings that the factor of the emergence of GG has actually been born in the context of globalization, especially after the collapse of communism and or the end of the cold war. When we look at the development of governance, this period occurred in the victory of Neoliberalism against the Communist countries. So at this moment there is also a wave of democratization in various countries after the collapse of some authoritarian regimes. With the democratization process, the concept of governance emerges and begins to develop. Governance is built precisely to limit the space of government, where the space for government movement is limited by the participatory mechanism of society [12], [13].

Speaking of who is benefited and harmed, let us see who is behind this GG concept. GG was born from the womb of the great agenda of globalization that was constructed by the ideology of Neoliberalism. Neoliberalism is one part of a hegemonic project that concentrates power and prosperity on the elite in the world, especially those who take advantage and interest financially within each country. An inseparable character is the system of using state power to require market and financial policies in a domestic process [6]. Neoliberalism is rapidly spread all over the world. They take advantage of advances in communications and media, and are confident that their ideas are spreading rapidly. They use international neoliberal credit providers such as the IMF and World Bank to promote the so-called "Washington Consensus". It is in this way that the capitalist ideology extends to regions ranging from Latin America to the East, India, and almost all countries in the African continent [14].

The Washington consensus as mentioned above has led to a slowly destructive concept of a country's economy such as free trade, export-oriented growth, financial capital mobility, deregulated labor markets and macroeconomic austerity policies [6]. So at the conclusion Neoliberalism seeks to dominate the economic sector and even power within a state in order to perpetuate their capitalist ideology within a country.

Obviously, the concept of GGs that ring with Neoliberalism and its capitalists benefits Neoliberalism itself. With the emergence of the IMF and the World Bank, as the actualization of this ideological institution became a way for Neoliberalism to penetrate the economy of poor and developing countries. By lending to poor and developing countries with the lure of economic improvement and development, at the end of this lending will only make poor and dependent countries dependent on international donor organizations. So the principle of dependence is created, so that the poor and developing countries are subject and obedient to all Neoliberalism systems and for non-obedient countries it will be lifted lending and with the threat of economic development in the country will experience obstacles. So that poor and developing countries will become dependent on all market mechanisms, economies and governmental arrangements all neoliberally wrapped up as a concept they think will improve governance, economy, politics and development in the poor and developing country, precisely with the entry of Neoliberalism into the economic, political and governmental system of a state, indirectly benefits their position to plunder the poor and developing country's economy and harm the poor and developing country.

A note about the World Bank is very plainly told below. clearly shows that the role of the World Bank in intervening in the economy of other countries, especially Third World Countries, Rittberger and Zangl [15] writes, since the 1970s the World Bank changed its concentration as the situation grew increasing economic gap between developing and developed countries. In that era, along with the independence of previously colonized countries, the number of developing countries is increasing. A note about the World Bank is very plainly told below. clearly shows that the role of the World Bank in intervening in the economy of other countries, especially Third World Countries, Rittberger and Zangl [15] writes, since the 1970s the World Bank changed its concentration as the situation grew increasing economic gap between developing and developed countries. In that era, along with the independence of previously colonized countries, the number of developing countries is increasing. Developing countries demand a more equitable distribution of welfare and developed countries meet these demands by supplying development funds in developing countries. The World Bank's financial base is the capital invested by the member country of this bank totaling 186 countries. The five largest shareholders in the World Bank are the US, France, Germany, Britain and Japan. The five countries have the right to assign one Executive Director each and they will vote for the President of the World Bank. Traditionally, the President of the World Bank is a US person because the US is the largest shareholder. Meanwhile, 181 other countries are represented by 19 Executive Directors (one Executive Director will be representative of several countries).

The World Bank played a major role in re-establishing the liberal post-World War II economic order. The redevelopment of the liberal economic order was led by the United States with a major draft of establishing a liberal world trade order. To achieve this goal, it is necessary to establish a monetary order based on a currency free to convert. Rittberger and Zangl [15] wrote, "The Bretton Woods Agreement obliges states to guarantee the freedom of their currencies to convert and maintain stable exchange standards against the US Dollar." The institutions responsible for maintaining monetary stability are IMF (International Monetary Funds) and IBRD (International Bank for Reconstruction and Development). IBRD is then often called "World Bank". The establishment of the World Bank and IMF in 1944 was followed by the establishment of a world trade order through an agency called GATT (General Agreement on Tariffs and Trade) in 1947. In 1995, GATT evolved into the WTO (World Trade Organization). Although the task of the World Bank is to 
regulate monetary stability, but in practice, the World Bank greatly influences global politics as almost all countries of the world are recipients of World Bank debt. Since the beginning of its operation, the World Bank has influenced the domestic politics of the country that became its perpetrators. The World Bank's first debt recipient was France, ie in 1947, with a loan of $\$ 987$ million. The loans are granted on strict conditions, including staff from the World Bank overseeing the use of the funds and keeping France from paying off debts to the World Bank rather than its debts to other countries. The US also intervened in this process of debt disbursement. The US Interior Ministry asked France to issue communist groups from the government coalition. Just a few hours after France complied with the request, the loan was liquid. The policies adopted by the World Bank affecting the political and economic policies of a country are called SAP (Structural Adjustment Program). If countries want to ask for additional debt, the World Bank orders that the recipient country's debt "policy change" (set out in SAP). If the country fails to implement SAP, the World Bank will impose fiscal sanctions. The policy changes set out in SAP are, among others, free market programs, privatization and deregulation. It is clear from then that Neoliberalism wants them to benefit from what they earn, through capitalism they have neatly wrapped up and then interweave with their established institutions the World Bank, the IMF or the WTO, they begin to expand ideologically to developing countries the end of which makes the developing country will have a principle of reliance on Neoliberalism.

Furthermore, GG creates a good and efficient governance, not least to establish governance in a discipline of market mechanisms. With a concept that the role of government should also be supported by the market and society. The point is how foreign companies belonging to neoliberalism can enter into a poor or developing country, which in turn will also harm the economy of the developing world. With the advent of a free-market economy, it is clear that populist economies are increasingly out-competing, for example small traders will lose out in the presence of malls and private markets.

It is clear that the GG concept is a project of actualizing an ideology of Neoliberalism that indirectly expands the system of government, economy and politics of other countries. With the establishment of IMF, WTO, and World Bank agencies, obviously the way for Neoliberalism to seek profit in other countries by intervening in the form of establishing an effective and efficient governance system that ends up disciplining market mechanisms, lending to state development the end is the dependence of the debtor country, the privatization project that will affect the populist economy, establish a Multi National Corporate company that ends is the control of the economic sector of other countries.

With all these criticisms, and the emergence of SG as a concept that will color the governance. It certainly has a new hope for the good and development of the nation-state. Especially the third world countries still in the process of carrying out development. As explained earlier, SG was born with two things that reflect the concept's newness, namely awareness of the influence of international factors and the importance of recognition of local culture in governance [9]. Then Putra [9] goes on to explain that not only those two possessed by SG as a concept born as a critique of GG, things like innovation, changes in how to see the configuration of actors in governance as well as the various dimensions that exist, are also very important in understanding this SG concept. GG problem is not lies in the concept but the way of implementation. Because implementation strategies that tend to be enforced and uniform is done in the GG concept by not including the institutions of uniform (donor) it as part of government problems [9].

Another thing that reinforces that GG is a tool to perpetuate the inequality that exists in globalization is related to the separation of the three basic elements of the country namely government, state civil society market players [9]. By embracing the three basic elements, the way GG defines them precisely gives the impression that these three things are separate from one another. GG is judged to deny the basic foundations of a country, and this is where the role of the state becomes weak and predictable [9]. SG is present to respect cultural diversity in the practice of public administration in different parts of the world. SG becomes important in this context because it looks at the process of development of public administration can not be uniformed globally. Developing countries have their own problems and dimensions in their public administration. Similarly developed countries. So SG suggests a different approach and theoretical paradigm to approach one country with another. Herein lies the importance of local culture in government reform. Some of the failures that have existed in the application of government are due to many culturally incomplete theories and concepts [9]. SG has a very serious concern over the aspects of local culture in the establishment of governance systems around the world. Therefore, SG from the beginning tidka want standardization and rigid to measure the quality of governance. For it will only deny the reality of how diverse the world is, and governance is the instrument that governs people, society, and civilization [9].

SG has a different view and instead promotes respect for the diversity of bureaucratic conceptions and governance, especially the basic values of traditional government culture that has been buried. In the SG it is very concerned with the local culture-based governance system that has begun to be largely ignored and this also happens in many countries. This occurs because the construction of Weber's bureaucratic concept that colored the development of public administration science including the birth of GG is a form of local cultural slaughter in the governance system. SG emerged to provide an opportunity to save the diversity of local culture in coloring the concept of governance. Then SG also has a different view in the context of the process of reaching a goal. Nevertheless in the SG rather than discuss the debate over how the principles are done to achieve the goal. Although SG still 
requires a universal basic prerequisite for democracy, transparency and accountability, it emphasizes flexibility and innovation to achieve that goal, and innovation becomes the spirit of SG implementation of the governance system [7].

So with the explanation above, SG was born as a new discourse that emerged as a critique of GG that gives the term "Sound" to replace "Good" is in order to respect the reality of diversity. Therefore, SG in governance reopen the absent variable opportunities of local wisdom due to the "Good" hegemony term and the impact of international co-opative forces. SG Recognizing that non-western concepts are actually much applicable, especially in the field of government. In addition, SG in principle also provides a space for tradition or innovation on how the state and government should be organized, in accordance with customs, cultures and local contexts. Of course the universal measure of people's welfare and respect for basic rights must be upheld [3].

\section{CONCLUSION}

GG and SG are the two concepts that have different characteristics, GG is a concept that puts forward the values of the process, with three actors as implementing agents ie government, private, and civil society, while SG put forward the goal values, with four actors as agents implementation ie government, private sector, civil society and international world. But GG emphasizes more on uniformity. This makes the state as if forced by the process set by the GG concept. GG is considered to prioritize the interests of the market than the interests of the country itself. While SG was born as an answer in the process of globalization. SG has an emphasis on diversity, complexity and tension. But these three require the entity involved to work harder in achieving the state's goals. SG focuses more on innovation in policy and administration. In addition, SG is also more emphasis on local values in the development of governance. Thus GG may have to make more improvements over the concept that has been formulated while the future SG is expected to be an implementive concept for a governance in a country.

\section{ACKNOWLEDGMENT}

In this study, the authors are very grateful for the concept created by Ali Farazmand in a book titled "Sound Governance-Policy and Administrative Innovation". With this book, the authors become very helpful in outlining an idea to do a comparison between GG and SG concepts. Thanks also to Sedarmayanti with her book on "Good Governance." So these two concepts can be reviewed for the development of the author's scholarship on both concepts.

\section{REFERENCES}

[1] Dwiyanto, Agus. Mewujudkan Good Governance Melalui Pelayanan Publik. Gajah University Press. Yogyakarta. 2008

[2] Sedarmayanti. Good Governance Kepemerintahan yang Baik Bagian Pertama. Mandar Maju. Bandung. 2012

[3] Anonim. Analisa Kritis Good Governance dan Paradigma Baru Arah Pembangunan di Era Globalisasi. 2017

[4] Sedarmayanti. Good Governance (Kepemerintahan yang Baik) Dalam Rangka Otonomi Daerah. Mandar Maju. Bandung. 2003

[5] Sumarto, Hetifah. Sj. Inovasi, Partisipasi dan Good Governance. Yayasan Obor Indonesia. Bandung. 2009

[6] Wiratraman, Herlambang Perdana, 2007. Neoliberalisme, Good Governance dan Hak Azasi Manusia. Jurnal Hukum Jentera, XV, (2-6)

[7] Farazmand, Ali. Sound Governance Policy and Administrative Innovations. Praeger Publisher. USA. 2004

[8] Syakrani. Syahriani. Implementasi Otonomi Daerah Dalam Prespektif Good Governance. Pustaka Pelajar. Yogyakarta. 2009

[9] Putra, Fadillah. Senjakala Good Governance. Averroes Press. Malang. 2009

[10] Dwipayana, Ari dan Eko, Sutoro. 2003. Membangun Good Governance di Desa. IRE: Yogyakarta

[11] Effendi. 2005. Membangun Good Governance Tugas Bersama Kita.

[12] Suranto, 2012. Jurus-Jurus Kapitalisme Menguasi Dunia. Makalah disajikan pada Mata Kuliah Governance dan Kebijakan Publik di Magister Ilmu Pemerintahan Universitas Muhammadiyah Yogyakarta, Yogyakarta, Oktober 2012

[13] Suranto. 2012. Kepemerintahan yang Baik. Makalah disajikan pada Mata Kuliah Governance dan Kebijakan Publik di Magister Ilmu Pemerintahan Universitas Muhammadiyah Yogyakarta, Yogyakarta, Oktober 2012

[14] Wibowo dan Wahono, Francis. Neoliberalisme. Cinderalas Pustaka Rakyat Cerdas: Yogyakarta

[15] Http.www.angga.blog.esaunggul.ac.id. didownload tanggal 12 November 2012 